\title{
AUV に搭載可能な海底土類採取装置に関する研究
}

\author{
Development of the bottom sampler for autonomous underwater vehicle
}

\author{
○学 横道 匠（九工大） 正 石井 和男（九工大, JST/CREST)
}

Takumi YOKOMICHI, Kyushu Institute of Technology, yokomichi-takumi@edu.brain.kyutech.ac.jp Kazuo ISHII, Kyushu Institute of Technology

\begin{abstract}
In order to analyze the ecosystem of unknown underwater creatures, the investigation into the seabed (or sampling of living things) is inevitable and underwater robots are expected as tools to access deep ocean. Most of investigations are carried out by using ROV or HOV, however the search area is limited to spot area because of their tethered cables, operation costs and number of robots. If AUVs can carry the devices for sampling underwater creatures, sand and mud, the cost of the examinations would be reduced, and wide area of investigation can be realized.
\end{abstract}

Key Words: Robot, Autonomous underwater robot, Manipulation

\section{1. はじめに}

近年，うなぎの産卵場所の発見が話題になったように，水 棲生物に関して身近な生物でありながらも生態系が解明され ていない事例が多い. 特に海底生物は, 高圧環境である熱水 地帯，ガスハイドレート地帯などにも生息しているものの， 観測装置が限られているため詳しい生態系が解明されていな い。これまで, これら海底生物群集は, 遠隔操緃式無人潜水 機（ROV）や深海有人潜水艇（HOV）によって，局所的ある いはラインワイズに調査されてきた[1]. 調査時間は数時間で あり，頻度も限られている。これまで特定物サンプリングお よび海底ドリリングは ROV や HOV により行われてきたが, AUV により全自動で行う技術が開発できれば，大がかりな ROV オペレーションシステムや船上設備を必要としない効率 的な海底調查システムを構築することが可能となり, 深海底 の総合的科学的調查が大きく推進される. また, 小型船でも 運用可能な AUV 部隊を同時展開することができれば, 少ない Ship Time で多様な観測が可能となる．総合的な同時観測を実 現することで, 新たな視点での海底生態系の研究を推進させ, 資源開発における生物多様性保全のための環境調査が可能と なる。

本研究では, 近年技術発展の著しい自律型海中ロボット (AUV) [2][3] をプラットフォームとし, 底生生物の面的な 広がりをみせる海底の特定生物あるいは周辺環境をなす海底 土等をサンプリング，コアリング，ドリリング等によって， 詳細な生態系および環境を明らかにすることを目的とする.

研究の第一段階として, 海底土類や特定生物をサンプリン グ可能な装置の開発する. 第二段階として, AUV の海底作業 を行う制御システムを向上させる、第三段階としてドリリン グ・コアリング可能なシステムを開発する.

\section{2. サンプリング装置}

本研究目的の第一段階であるAUVによる海底土のサンプリ ングを遂行するためのサンプリング装置を提案した[4]. しか し，そのサンプリング装置が未知の環境下であっても，全自 動で安定的かつ安全に動作できる採泥可能なシステムを考え る必要がある（Fig. 1）。

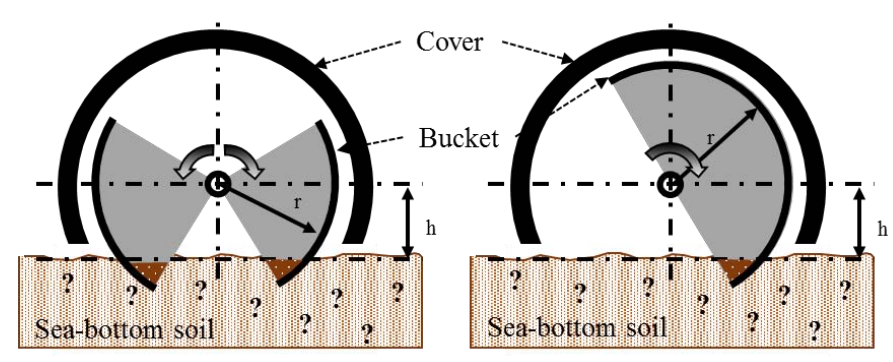

Fig. 1 The grab bucket dredger

\section{1 採泥可否判定装置}

海底でのサンプリングには，様々な環境が予想される。そ のすべてに対応することは困難であり，現実的ではない，ま た, バケットの強度や駆動系のトルクを算定するにあたり, 対象のモデル化を行うが，それも困難である。そこで，確実 かつ安全にサンプリング可能かどうかの判定をその場で行え る装置を開発する.

海底土などの砂を掬うということは，砂に対してバケット 先端がめり込み, 対象を空間的に隔離した状態である.よっ て，掬えるかどうかの判断を一種のめり込み強度試験のよう なものを行い, その結果から判定を行う。一般的なめり込み 強度試験は，単一の材料に行われるが，これを砂・泥などの 混在物である一つの材料として考える. また，通常のめり込 み試験とは異なるため, バケットの採泥能力を考慮して基準 を設けるものとする.

\section{2 基礎実験の概要}

採泥可否判定装置の基礎実験として，海底土に見立てた試 料に対して試験片(Bit)を挿入し，その反力を計測する(図 2). 乾いた砂と十分な水分に浸した水没砂の 2 種類の試料に対し て，Bitを挿入し，その反力を測定する．直棒状の Bit を垂直 に挿入するストレートタイプの試験と円弧状に湾曲した Bit を挿入する円弧タイプの試験を行う。また，Bit 先端の断面は バケット先端辺の単位面としており，Bitを重ねたときに反力 がどのように推移するかを観察する．同様に，Bitの先端形状 が変化 (円弧端) した場合についても計測した.

条件統一のために，試料面高さを常に一定に保つ必要があ る. そのため, 試験毎に試料をほぐし, 均し器で平坦にする. 


\section{3 実験装置}

実験装置は，地面に対して垂直に挿入するストレートタイ プとサンプリング装置で想定しているグラブタイプのバケッ トと同様のアプローチを行う円弧タイプがある.

(a) ストレートタイプ

実験装置の概要図を Fig. 5(a)に示す. 試料面に対して垂直に 挿入されるようにリニアレールと 2 つキャリッジによって 1 自由度に制限し，スライダ間に力覚センサ(FSR400)を配置す ることで，取り付けられるセンササイズに汎用性を持たせて いる．垂直上下動作は平歯車とラックギアによって行い，駆 動モーター(KONDO 製 KRS4014)内のポテンショメータから 直接可変抵抗值を読み取り, Bit 位置の取得と装置の簡素化を 図っている。上下ストロークは最大 $50[\mathrm{~mm}]$, 試料に挿入され る深さを $30[\mathrm{~mm}]$ とし，最大突出力を $10[\mathrm{~kg} \cdot \mathrm{f}]$ としている.

\section{(b) 円弧タイプ}

実験装置の概要図を Fig. 5(b)に示す. 固定フレーム下部に円 弧形状をした Bit を取り付け，プーリ 2 を回転させると Bit も 回転する.モーター側にも同様にプーリ 1 を取り付けており, プーリ 1,2 間は，ワイヤで接続され，連動するようになってい る. 張ってあるワイヤの間に引っ張り式の圧力センサを設置 し，Bit回転時に掛かるトルクを計測できるようにしている. 試料面と Bit 先端面が平行の状態を初期位置とし, 回転角度を 180[deg] とする. Bit の曲率半径は $35[\mathrm{~mm}]$. 最大トルクは, $20[\mathrm{~kg} \cdot \mathrm{cm}]$ である.

\section{4 実験結果}

ストレートタイプ及び円弧タイプの実験結果について述べ る. また，Fig. 6 Fig. 9の凡例については，それぞれハイフ ンで区切られた要素は “[先端形状]-[Bit 枚数]-[砂の状態]”を表 している．例えば,” sq-t2-d “であれば，矩形端”sq”の Bit が 2 枚”t2”あり，試料は乾いた砂”d”である. ストレートタイプの 凡例は Table 1 に, 円弧タイプは Table 2 に詳細を示す.

ストレートタイプの Bit 変位值 (上段) と駆動モーターの出 力電流（下段）を Fig. 6 に示寸．乾燥砂，水没砂共に，電流值 の変化は Bit 挿入途中において, 微量であり, “sq-t1-w” と” sq-t3-w”のピーク值の差が 124[mA]である. それに対し， リップル電流の振幅值が 20〜 70[mA]である. 円弧タイプのモ ーター電流值も Bit 挿入前後の変化と同程度のリップルがあ る (Fig. 8). Bit が指定深さでの停止状態時に，いくつか突出 した電流值が計測されているが，これは，モーターの位置制 御の摺動時に生じる突入電流であると考えられる.

ストレートタイプの Bit 変位值 (上段), 乾燥砂の力覚セン サ值（中段）及び水没砂の力覚センサ值を Fig. 7 に示す. Bit 挿入時において, Bit 数 1 本のとき, 水没砂は, 乾燥砂より貫 入力が少ないが， Bit3 本時は水没砂の方がより力が必要とな っている.また, 乾燥砂に比べ, 水没砂は Bit 先端形状変化に

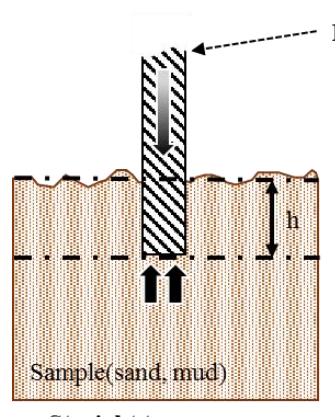

Straight type

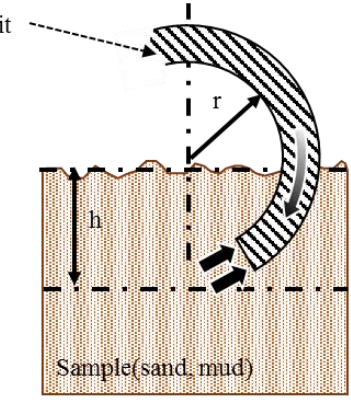

Circular type
よるピーク值の差は少ない.

円弧タイプの Bit 変位值 (上段), 乾燥砂及び水没砂の力覚 センサ值（下段）を Fig. 9 に示す．図中の破線位置が Bit の最 深部にあたる．破線前後の過渡部分では水没砂の方がより， 力が必要となっている。 しかし，力覚センサ值の軌跡がス卜 レートタイプと異なり, ピーク值到達が速く, 平坦な形状と なっている。これは，円弧タイプではストレートタイプと異 なり，非線形な幾何学特性が影響していると考えられる。ま た，水没砂の Bit 回転後の停止状態では，同じ值に収束おり， 砂による反力が一定であると考えられる.

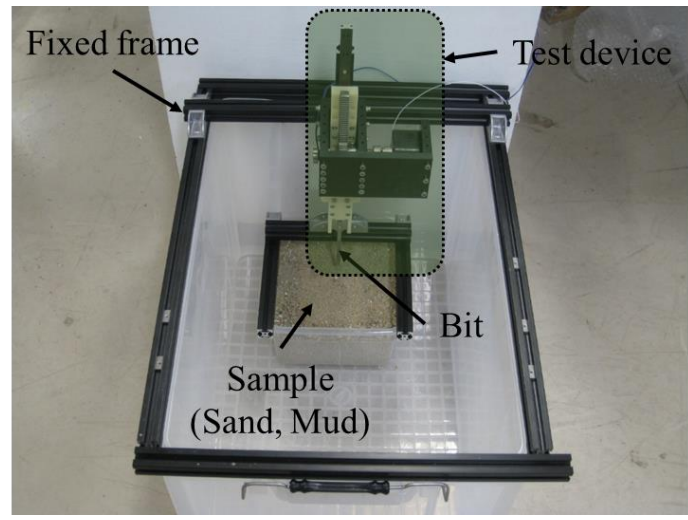

Fig. 3 Top view of the experiment setup (straight type)

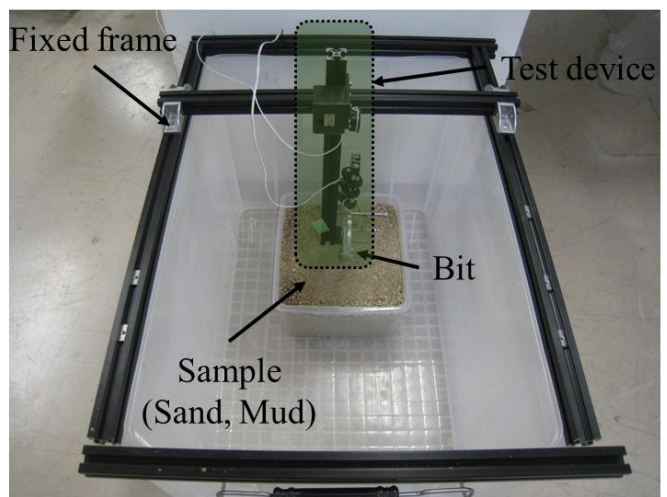

Fig. 4 Top view of the experiment setup (circular type)

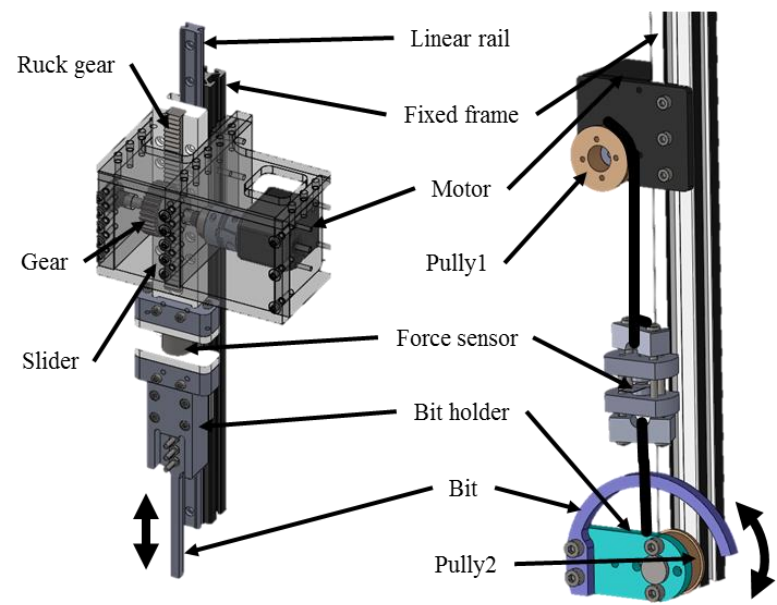

(a) Straight type

(b) Circlar type

Fig. 5 Structure of the test device

Fig. 2 The efforts of insert Bits 

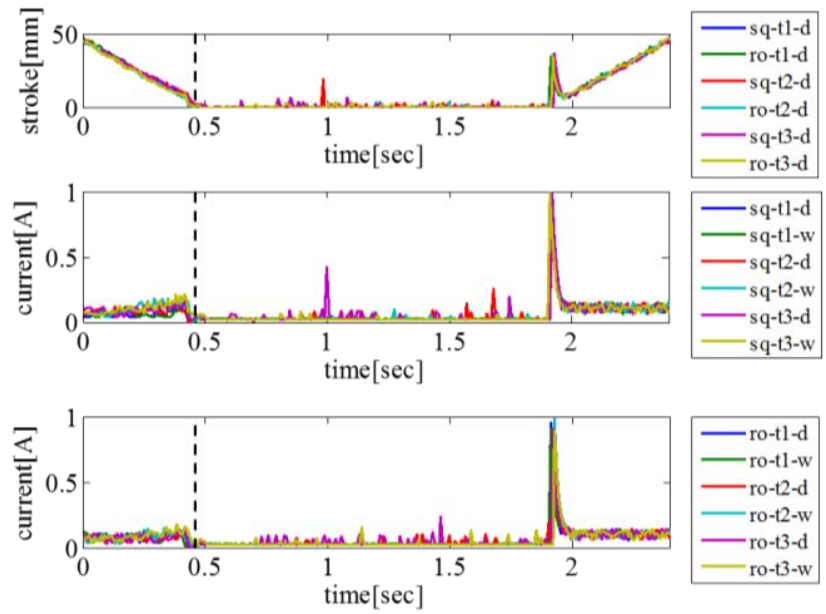

Fig. 6 Motor current of the straight type
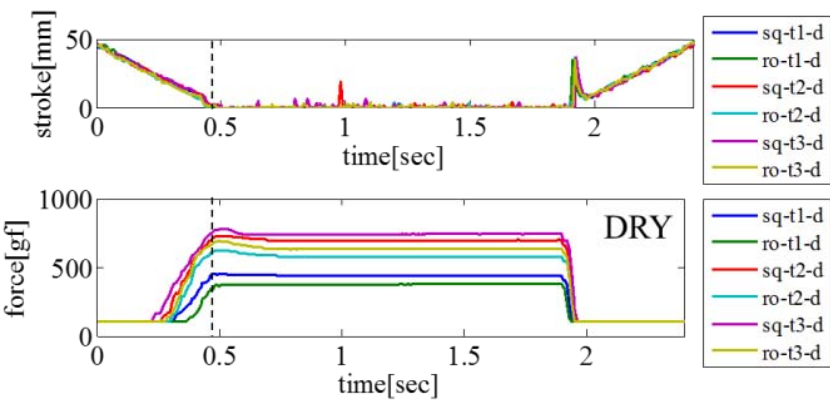

- $\mathrm{sq}-\mathrm{ti}-\mathrm{d}$

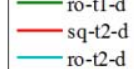
sq-t3-d ro-t3-d
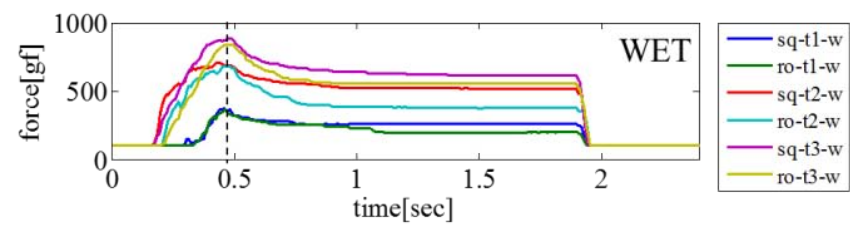

Fig. 7 Force sensor value of the straight type
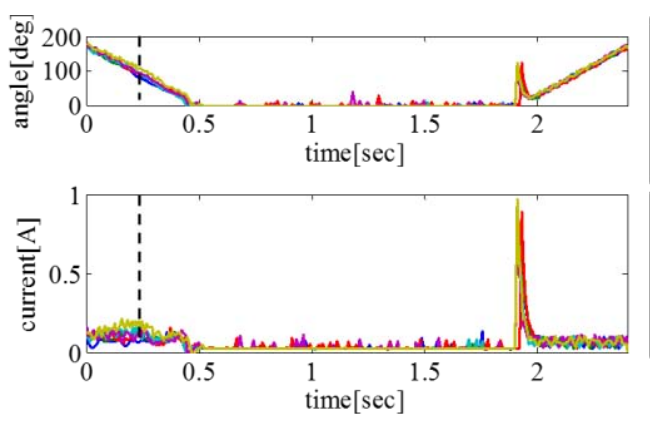

Fig. 8 Motor current of the circular type
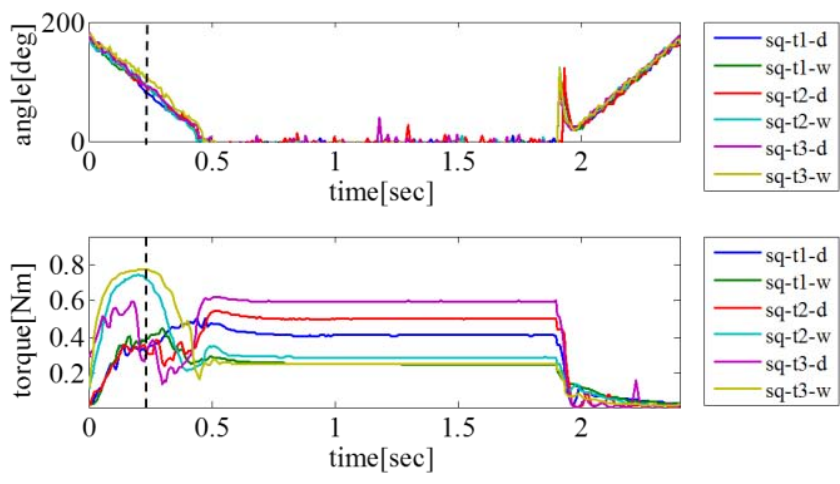

Fig. 9 Force sensor value of the circular type
Table 1 Description of test methods for legends in fig. Fig. 6,Fig. 7

\begin{tabular}{|c|c|c|c|c|c|c|}
\hline \multirow{2}{*}{$\begin{array}{c}\text { Straight } \\
\text { type }\end{array}$} & \multicolumn{2}{|c|}{ Bit:1枚 } & \multicolumn{2}{|c|}{ Bit:2枚 } & \multicolumn{2}{|c|}{ Bit:3枚 } \\
\cline { 2 - 7 } & 方形端 & 円弧端 & 方形端 & 円弧端 & 方形端 & 円弧端 \\
\hline 乾燥 & sq-t1-d & ro-t1-d & sq-t2-d & ro-t2-d & sq-t3-d & ro-t2-d \\
\hline 水没 & sq-t1-w & ro-t1-w & sq-t2-w & ro-t2-w & sq-t3-w & ro-t2-w \\
\hline
\end{tabular}

Table 2 Description of test methods for legends in fig. Fig. 8, Fig. 9

\begin{tabular}{|c|c|c|c|c|c|c|}
\hline \multirow{2}{*}{$\begin{array}{c}\text { Circular } \\
\text { type }\end{array}$} & \multicolumn{2}{|c|}{ Bit:1枚 } & \multicolumn{2}{c|}{ Bit:2枚 } & \multicolumn{2}{c|}{ Bit:3枚 } \\
\cline { 2 - 7 } & 方形端 & 円弧端 & 方形端 & 円弧端 & 方形端 & 円弧端 \\
\hline 乾燥 & sq-t1-d & - & sq-t2-d & - & sq-t3-d & - \\
\hline 水没 & sq-t1-w & - & sq-t2-w & - & sq-t3-w & - \\
\hline
\end{tabular}

\section{5 考察}

(a) モーター電流

高トルクモーターを使用した事により，反力に対する電流 值の明確な反応を読み取れないことが分かった。よって，バ ケットの駆動部を高トルクに設定した場合, モーター電流の みのセンシングで採泥可否判定は困難であると考えられる.

(b) 力覚センサ值

乾燥砂は，Bit 挿入時の反力がピーク時からの減少が少ない のに対し, 水没砂は Bit 停止後緩やかに反力が減少する傾向で ある。これは，砂粒子間の水分量が増えることで，砂粒子を 移動させやすくしているのだと考えられる． Bit 1 本の場合だ と乾燥砂のほうが水没砂より低反力であるが，Bit 3 本の場合 では，水没砂がより最大反力が大きい．水分を含むことでの 試料の粘性と Bit の接触表面積が関係していると考えられる. このため, 採泥可否の判定を行うために用意する試料は，乾 燥砂ではなく，十分水分を含んだ試料を用いなければならな い事が分かった。

\section{3.お りりに}

研究目的の第一段階として, 海底土類をサンプリングする 上で不明な対象であっても安定的且つ安全に行えるシステム の構築を行うための基礎実験を行った．得られた結果から採 泥可否判定装置及び，サンプリング装置の開発を進め，AUV による海底土類のサンプリング実現を目指す.

\section{謝 辞}

本研究は JST/CREST の支援により実施している.

\section{文 献}

[1] 上嶋 正人, 西村 清和, 岸本 清行, 弘松 峰男, 佐藤 幹夫, 松 本 良. 上越沖, ”海底表層メタンハイドレート賦存域での深海 底構造・微地形調查について”。地学雑誌. 2009, Vol. 118, No. 1, p.72-92 .

[2] 前田 文孝, 巻 俊宏, 高川 真一, 浅田 昭, “小型低周波音源及 び電力増幅器を用いた深海曳航型音波探査技術の開発”, 生産研 究 Vol. 63 (2011), No. 4 pp.583-586.

[3] 巻 俊宏, 浦 環, Hanumant Singh, 坂巻 隆. “自律型水中ロボッ トによる鹿児島湾たぎり噴気帯の 3 次元画像マッピング(第 3 報)-測位情報と視覚的特徵の併用による画像モザイキング手法 _“. 海洋調查技術. 2011, Vol. 23, No. 1, p.1_1-1_10.

[4] 横道 匠, 石井 和男, 小倉 将人 “AUV に搭載可能な海底生態 系への干渉装置に関寸る研究”, ROBOMEC2012, 2A2-F11, 2012 